\title{
Hydrothermal multivariable approach. Full-scale feasibility study
}

\author{
Sara I. Pérez-Elvira* \\ Departamento de Ingeniería Química y Tecnología del Medio Ambiente \\ Facultad de Ciencias \\ Universidad de Valladolid \\ C/ Dr. Mergelina, s/n-47011 Valladolid, España \\ Tel: 34983423172 \\ Fax: 34983423013 \\ E-mail: sarape@iq.uva.es \\ Fernando Fernández-Polanco \\ Departamento de Ingeniería Química y Tecnología del Medio Ambiente \\ Facultad de Ciencias \\ Universidad de Valladolid \\ C/ Dr. Mergelina, s/n 47011 Valladolid, España \\ Tel: 34983423172 \\ Fax: 34983423013 \\ E-mail: ffp@iq.uva.es \\ María Fernández-Polanco \\ Departamento de Ingeniería Química y Tecnología del Medio Ambiente \\ Universidad de Valladolid \\ C/ Dr. Mergelina, s/n 47011 Valladolid, España \\ Tel: 34983423172 \\ Fax: 34983423013 \\ E-mail: maria@iq.uva.es
}

Pilar Rodríguez

Sociedad Regional Abastecimiento de Aguas, S.A.

Aguas de Barcelona, Torre Agbar

Av. Diagonal 211, Barcelona, España

Tel: 34933422815

Fax: 34933422860

E-mail: prodiguez@agbar.net

\section{Philippe Rouge}

Sociedad Regional Abastecimiento de Aguas, S.A.

Aguas de Barcelona, Torre Agbar

Av. Diagonal 211, Barcelona, España

Tel: 34933422815

Fax: 34933422860

E-mail: prouge@agbar.net

Financial support: This work was supported by the Ministerio de Medio Ambiente y Medio Rural y Marino, España (Proyect 558/2006/2-4.3).

Keywords: anaerobic digestion, biogas, sludge, sludge properties, thermal hydrolysis.

$\begin{array}{ll}\text { Abbreviations: } & \text { AD: anaerobic digestion } \\ & \text { COD: Chemical Oxigen Demand } \\ & \text { TH: thermal hydrolysis } \\ & \text { TS: total solids } \\ & \text { VAF: volatile fatty acids } \\ \text { VS: volatile solids }\end{array}$

A process configuration combining thermal hydrolysis (TH) and anaerobic digestion (AD) of sludge has been studied with the objective of analysing the feasibility of the technology for full scale installations. The study has been performed through pilot scale experiments and energy integration considerations, and a scheme of the most profitable option is presented: thermal hydrolysis unit fed with $7 \%$ total solids (TS) secondary sludge, anaerobic digestion of the hydrolysed sludge together with fresh primary sludge, and a cogeneration unit to produce green electricity and provide hot steam for the thermal hydrolysis process. From a technical and

*Corresponding author 
practical point of view, the process scheme proposed is considered to be feasible. Based on the results of the pilot plant performance and the laboratory studies, the process has proven to operate successfully at a concentration of 7-8\% TS. After the thermal hydrolysis, sludge viscosity becomes radically smaller, and this favours the digesters mixing and performance $(40 \%$ more biogas can be obtained in nearly half the residence time compared to the conventional digestion). From an economic point of view, the key factors in the energy balance are: the recovery of heat from hot streams, and the concentration of sludge. The article presents the main energy integration schemes and defines the most profitable one: an energetically self-sufficient process, with a cogeneration unit. The scheme proposed has proven to need no additional energy input for the sludge hydrolysis, generates more that $1 \mathrm{MW}$ green electricity (246 kW surplus with respect to the conventional process), and produces $58 \%$ less volume of Class A biowaste. The study and balances here presented set the basis for the scale-up to a demonstration plant (hydrolysis + anaerobic digestion + cogeneration unit).

In order to face excess waste activated sludge management problems, many studies have been performed utilizing different principles (Pérez-Elvira et al. 2006). The option of on-site reduction in sludge quantity is the preferred choice, specially the anaerobic digestion. However, the rate limiting step of solid hydrolysis make necessary to implement a pre-treatment unit prior to the digester.

In an effort to improve sludge hydrolysis, many studies have been performed utilizing different methods of sludge pre-treatment (Tanaka et al. 1997; Chu et al. 1999; Déléris et al. 2000; Hasegawa et al. 2000; Müller, 2000; Neis et al. 2000; Lehne et al. 2000; Müller, 2001; Tiehm et al. 2001; Camacho et al. 2002; Déléris et al. 2002; Odegaard et al. 2002; Bougrier et al. 2004; Carballa et al. 2004; Goel et al. 2004; Müller et al. 2004; Odegaard, 2004). However, from a practical and operational point of view, there still remains the need for a cost-effective method.

Thermal pre-treatment has proven to be of great interest. The advantage of the combined $\mathrm{TH}+\mathrm{AD}$ process is that the energy input needed for the hydrolysis process is thermal energy, and could be satisfied from the energy production of the own process, resulting in a energetically selfsufficient process.

A combination of thermal hydrolysis and anaerobic digestion is widely investigated in literature from a laboratory-scale point of view, regarding disintegration and biodegradability (Li and Noike, 1992; Kepp et al. 2000; Kepp and Solheim, 2001; Fernández-Polanco et al. 2008; Pérez-Elvira et al. 2008).

The aim of this research is to recover the laboratory and pilot-scale information, and use it as the basis of an economic study, combining the thermal hydrolysis with a cogeneration plant.

\section{MATERIALS AND METHODS}

\section{Pilot plant}

The pilot plant combining thermal hydrolysis and anaerobic digestion is the one described in Fernández-Polanco et al. (2007), operated at the Municipal Wastewater Treatment Plant of Vic (Spain).

In the thermal hydrolysis unit, $10 \mathrm{~L}$ of sludge is heated to $170^{\circ} \mathrm{C}$ with direct steam injection for $30 \mathrm{~min}$. The pilot plant is equipped with automatic valves and a data acquisition and control system that control the steam inlet (to keep the desired operation temperature) and sludge outlet (steam explosion to the flash tank).

A $200 \mathrm{~L}$ mesophilic reactor is continuously fed with the hydrolyzed sludge. Biogas production is automatically recorded, and the digester performance and effluent characteristics are recorded from laboratory analysis (Chemical Oxigen Demand (COD), volatile fatty acids (VAF), pathogens, dewaterability and viscosity).

All the analyses were done using the procedures given in "Standard Methods for Examination of Water and Wastewater”, and described in Pérez-Elvira et al. (2008).

Anaerobic biodegradability was calculated following the methane production, using an automatic equipment and the experimental conditions described in Fernández-Polanco et al. (2005).

\section{Mass and energy balance considerations}

The quality of the sludge depends on the water treatment process, and both the energy content and the expected methane production vary from one type of sludge to another. It is therefore not possible to predict the amount of methane only by the sludge feeding rate of a digester.

The energy content of the sludge, measured as COD, differs within a range of 1,4 to $2 \mathrm{~g}$ COD/g VSS. In general, primary sludge presents higher values than biological sludge (due to the higher lipid content). Taking average values from a conventional digestion process, the expected methane production is between 150 and $300 \mathrm{~L} \mathrm{CH}_{4} / \mathrm{kg} \mathrm{VSS}$ feed.

For the present study, samples of primary and secondary sludge from the municipal WWTP of Vic have been characterised regarding COD, volatile solids (VS) and anaerobic biodegradability. Table 1 presents the results of the characterisation. Mixed sludge corresponds to $40 \%$ VS from primary sludge and $60 \%$ VS from secondary sludge.

The economic use of the biogas has been assessed considering yield parameters for commercial boiler and 
Hydrothermal multivariable approach. Full-scale feasibility study

Table 1. Sludge characterisation, and expected amount of methane gas from the digestion of sludge.

\begin{tabular}{|l|c|c|c|c|c|c|}
\hline \multicolumn{1}{|c|}{ Type of sludge } & $\mathbf{1}^{\mathbf{0}}$ & $\mathbf{1}^{\mathbf{0}}$ hydrol & $\mathbf{2}^{\mathbf{0}}$ & $\mathbf{2}^{\mathbf{0}}$ hydrol & mixed & mixed hydrol \\
\hline $\mathrm{g}$ COD/g VS & 1,8 & 1,8 & 1,4 & 1,4 & 1,6 & 1,6 \\
\hline$\%$ SVIST & $70 \%$ & $70 \%$ & $67 \%$ & $67 \%$ & $68 \%$ & $68 \%$ \\
\hline$\%$ VS degradation & $50 \%$ & $60 \%$ & $40 \%$ & $64 \%$ & $44 \%$ & $62 \%$ \\
\hline $\mathrm{L} \mathrm{CH}_{4} / \mathrm{kg} \mathrm{VS}_{\text {feed }}$ & 315 & 378 & 196 & 314 & 240 & 341 \\
\hline
\end{tabular}

10: primary sludge.

$1^{\circ}$ hydrol.: primary sludge after thermal hydrolysis.

$2^{\circ}$ : secondary sludge.

$2^{\circ}$ hydrol.: secondary sludge after thermal hydrolysis.

mixed: mixed sludge (40\% VS from primary, $60 \%$ VS from secondary).

mixed hydrol.: secondary sludge after thermal hydrolysis.

engine. Typical heat and electric power are presented in Table 2.

\section{RESULTS}

\section{Technical feasibility}

Three years research in laboratory scale and fourteen months operation in pilot plant support the practical feasibility of the thermal hydrolysis process studied (Fernández-Polanco et al. 2008).

As presented in Pérez-Elvira et al. (2008), the thermal treatment of fresh mixed sludge $\left(175^{\circ} \mathrm{C}, 30 \mathrm{~min}\right)$ disintegrates the floc structures, increasing four times the SCOD fraction and favouring the water removal: $10 \%$ TS concentration can be achieved by centrifugation, without polymer conditioning. Moreover, after the hydrolysis the sludge viscosity becomes radically smaller, which favours the digester mixing and, therefore, the performance.

The combined benefits of cell lysis, solubilization and rheology have also a positive effect on the sludge anaerobic digestibility and the rate of degradation. Figure 1 shows, for a period of 6 months, the performance of the $200 \mathrm{~L}$ anaerobic digester, directly fed with $3 \%$ TS mixed sludge thermically hydrolyzed in the hydrolysis unit. The hydraulic residence time was decreased step by step until it reached a stable value of 12 days. Oscillations in biogas production are caused by the variability of the sludge concentration, but $48 \%$ VS removal and $502 \mathrm{~mL}$ biogas/g $\mathrm{VS}_{\text {feed }}$ can be considered as a mean value.

Comparing the performance of the pilot digester with the full scale anaerobic digester of the WWTP (fed with nonhydrolysed sludge), $40 \%$ more biogas is obtained in nearly half the time (12 days instead of 20 days), and sludge production decreases by nearly $30 \%$. The digested sludge is pathogen free, and a 7\% DS cake can be achieved by centrifugation without the use of polymer conditioners, being the solids recovery rate above $95 \%$.

This performance results together with a proper economic study set the basis to assess the viability of the technology.

\section{Economic feasibility}

The economic advantage of the combined $\mathrm{TH}+\mathrm{AD}$ process is the possibility of getting the energy needed for the thermal process from the different integration possibilities, such as the recovery of heat from hot streams (like vapour produced in the flash, hydrolyzed sludge, exhaust gases and hot water from the gas engine to pre-heat the sludge), and the use of the biogas produced in the anaerobic digestion to generate the steam.

A proper scheme can drive to a self-sufficient process, as described below.

Initial energy balance and first energy integration. Figure 2 presents a scheme of an open process, where no energy integration is considered.

A simple balance to this system shows that working with a typical concentration of 3\% TS, and burning the biogas produced in the anaerobic digestion to get the steam, it would be necessary to communicate $61 \mathrm{kWh} /$ ton sludge to fulfil the energy requirements of the thermal hydrolysis. Having a self-sufficient process would drive to the necessity of working at a concentration of $9,1 \% \mathrm{TS}$, which is too high to be possible.

Therefore, some kind of energy integration has to be considered.

The first and more evident configuration scheme consists of the recovery of heat from the flash vapour outlet, presented 
Table 2. Expected energy recovery from biogas, in a boiler or in an engine.

\begin{tabular}{|l|c|c|}
\hline & Boiler Gas engine \\
\hline Electrical efficiency (\%) & - & $37 \%$ \\
\hline Electric power $\left(\mathrm{kWh} / \mathrm{Nm}^{3} \mathrm{CH}_{4}\right)$ & - & 4,0 \\
\hline Heat power $\left(\mathrm{kWh} / \mathrm{Nm}^{3} \mathrm{CH}_{4}\right)$ & 10,8 & 4,35 \\
\hline
\end{tabular}

in Figure 3. In this new scheme, the heat demand to operate the process with mixed sludge 3\% TS (again burning the biogas to produce steam) is $14 \mathrm{kWh} /$ ton sludge. This configuration allows to work at a concentration of $4,4 \%$ TS for a energetically self-sufficient process.

Further energy study: feed segregation and steam generation devices. In order to exploit the energy integration possibilities, some other factors must be taken into account. These factors influence the economics of the process, and are related to: 1 ) the possibility of including or not the primary sludge in the thermal treatment, and 2) different alternatives to get energy from the biogas produced (boiler or gas engine).

Figure 4 show the different configurations studied.

From the balances presented, some conclusions can be drawn:

First, it can be noticed that it is a better option to segregate primary from secondary sludge (scheme B), in order to treat in the thermal hydrolysis unit only the biological sludge. Only $8 \%$ more energy biogas production is achieved in the scheme B, compared to the $39 \%$ more energy needed when treating the whole mixed sludge flow (scheme A).

The reason for this is that primary sludge presents a high biodegradability (315 $\mathrm{L} \mathrm{CH}_{4} / \mathrm{kg} \mathrm{VS}$ feed), and therefore the energy needed to treat the primary sludge in the thermal unit is too high compared to the subsequent little increase in biogas.

Second, the use of a boiler or a gas engine was compared. The installation of a combined heat and power system allows getting not only thermal energy, but also electricity. As will be presented later on, the key factor in the energy balance is the sludge concentration. Table 3 presents the energy balance for a typical concentration of 3\% TS, for both configurations, boiler and gas engine. It can be seen that working with a $3 \%$ TS concentration, the only energetically self-sufficient scheme is segregating the primary sludge and using a boiler (Figure 4c).

For higher feeding concentration, the balances are presented below.
More insights into the energy balance: influence of the concentration. As has been stated before, the key factors in the energy balance are the recovery of heat from hot streams, and the concentration of sludge.

Although the recovery of heat from the flash vapours reduces the quantity steam needed (from 297 to $142 \mathrm{~kg} / \mathrm{ton}$ sludge), the sludge concentration is key to limit the amount of energy wasted heating water, and get a self-sufficient process.

The purpose of this study is to define the input concentration that optimizes the process. If the energy liberated during electricity generation in a combined heat and power system is enough in quantity and quality to fulfil the sludge heating requirements, then the proposed system would be energetically self-sufficient and the whole increase in biogas production could be used for electricity generation.

For the different configurations presented above, an energy balance has been done. The results are presented in Table 4 .

It can be seen that the boiler allows to get a self-sufficient process working at a lower concentration, but does not offer the possibility of getting green energy. As long as the working concentration is technically possible, the combined heat and power system is advantageous. Table 4 shows that segregating primary from secondary sludge (scheme B) allows to reduce the concentration of the feeding from 11 to $7 \%$ TS for a self-sufficient process.

Therefore, the operation scheme considered more profitable is the one presented in Figure 4d. The technical viability of working at a $7 \%$ TS sludge concentration has been proved during the last 6 months operation of the pilot plant, and a deeper economic analysis for this case is now presented.

Final energy integration scheme. Once defined the process operation scheme, a mass and energy balance was done, considering a 500.000 inhabitants municipal wastewater treatment plant.

Figure 5 presents the balance for a conventional $A D$ scheme (for a typical 3\% TS mixed sludge feeding), and Figure 6 corresponds to the proposed $\mathrm{TH}+\mathrm{AD}$ scheme (with a thermal hydrolysis unit fed with $7 \%$ TS secondary sludge before the anaerobic digester).

A combined heat and power system to produce electricity from biogas is considered in both schemes.

Comparing both schemes, some discussion can be done:

Increase in biogas production and electric energy generation: The hydrolysis of secondary sludge increases biogas production by $30 \%$ (from 5.075 to $6.545 \mathrm{~m}^{3}$ $\mathrm{CH}_{4} /$ day), and allows to get a corresponding $30 \%$ more electric power in the gas engine. The green electricity generation is $1.093 \mathrm{~kW}$ (considering a 37\% yield), which 
Table 3. Energy balance for a typical concentration of $3 \% \mathrm{TS}$, for both configurations, boiler and gas engine.

\begin{tabular}{|c|l|c|c|}
\hline & & $\begin{array}{c}\text { Thermal energy needed } \\
\text { kWh/day }\end{array}$ & $\begin{array}{c}\text { Thermal energy produced } \\
\text { kWh/day }\end{array}$ \\
\hline \multirow{2}{*}{ Boiler } & (A) Mixed sludge & 44.669 & 30.779 \\
\cline { 2 - 4 } & (B) $1^{\circ}$ non-hydrol $+2^{\circ}$ hydrol & 27.269 & 28.493 \\
\hline \multirow{2}{*}{ Gas engine } & (A) Mixed sludge & 111.156 & 30.779 \\
\cline { 2 - 4 } & (B) 10 non-hydrol + 20 hydrol & 67.857 & 28.493 \\
\hline
\end{tabular}

represents a surplus of $246 \mathrm{~kW}$, with an associated value of $384.646 \$ / y$.

No energy input needed for the TH process: Supposing a gradient between 520 and $200^{\circ} \mathrm{C}$, the heat recuperation from exhaust gases in the $\mathrm{TH}+\mathrm{AD}$ plant allows preheating the sludge feeding to more than $90^{\circ} \mathrm{C}$. This energy balance proves that the co-generation unit liberates enough heat energy $(1.187 \mathrm{~kW})$ to produce the steam needed to guarantee an energetically self-sufficient process.

Smaller footprint: After the hydrolysis, the sludge becomes $70 \%$ less viscous, and this favours the sludge dewaterability and allows working at a higher concentration in the digester. Working at 7\% TS concentration (instead of the conventional 3\% TS) reduces the digester volume by $58 \%$ (from 8.600 to $20.400 \mathrm{~m}^{3}$ ). The digester capacity can be enhanced even more by reducing the residence time from 20 to 12 days. As presented before, pilot-scale studies showed a very good performance in a 12-day digester fed with 3\% TS mixed hydrolysed sludge. Regarding viscosity, further research is needed to evaluate the impact of rheology on mixing power and cost.

Biowaste generation and characteristics: Regarding the sludge generation, the combined process reduces by $26 \%$ the TS production (from 17, 1 to 12, 7 ton ST/d). The better dewaterability of this biowaste drives to a higher TS concentration in the cake (from $4 \%$ to $7 \%$ DS, obtained in laboratory studies, Pérez-Elvira et al. 2008), and therefore to a corresponding $58 \%$ smaller volume of biowaste to disposal $\left(181 \mathrm{~m}^{3} / \mathrm{d}\right.$ instead of the $429 \mathrm{~m}^{3} / \mathrm{d}$ in the conventional process). The dewatering energy consumption and operators costs decrease, as a consequence of shorter dehydration time. In general, handling, storage, transportation (and greenhouse emissions from trucking) and disposal costs are drastically reduced.

Furthermore, the digested sludge is pathogen free, and meets US EPA Class A criteria.

\section{CONCLUDING REMARKS}

A process scheme combining anaerobic digestion and thermal hydrolysis was studied through pilot scale experiments and energy integration considerations. The scheme defined as more profitable consists of a thermal hydrolysis unit fed with 7\% TS secondary sludge, followed by the anaerobic digestion of the hydrolysed sludge together with fresh primary sludge. A cogeneration unit is used to recover energy from the biogas.

The technical feasibility of the system working with 7-8\% TS sludge has been proven from the pilot plant performance. Laboratory studies show the beneficial changes of the sludge properties with respect to viscosity (digesters mixing and performance) and dewatering characteristics (sludge volume reduction). No operational problems have been observed.

The main economic advantage of the scheme proposed is that the energy input needed for the hydrolysis process can be satisfied from the energy production of the own process, resulting in a energetically self-sufficient process. Some other benefits that support the economic feasibility of the technology are:

- $58 \%$ smaller foot print of the digesters, as a consequence of working at a higher input (7\%TS) concentration and less residence time (10-12 days).

- Increase in biogas production by $30 \%$.

- $30 \%$ increase in electricity generation, which represents a surplus of $246 \mathrm{~kW}$, with an associated value of $384.646 \$ / y$.No energy input needed for the $\mathrm{TH}$ process.

- Reduced TS production in the final biowaste by $26 \%$. The better dewaterability of the waste drives to a $58 \%$ smaller volume of biowaste to disposal. 
Table 4. Energy balance for a self-sufficient process, for configurations, boiler and gas engine.

\begin{tabular}{|c|c|c|c|c|c|}
\hline & & \multicolumn{2}{|c|}{ Thermal energy ${ }^{a}$} & \multirow{2}{*}{ Electrical output, kW } & \multirow{2}{*}{$\% \mathrm{TS}^{b}$} \\
\hline & & kWh/day & kW & & \\
\hline \multirow{2}{*}{ Boiler } & (A) Mixed sludge & 76.592 & 3.191 & - & $4,4 \%$ \\
\hline & (B) $1^{\circ}$ non-hydrol $+2^{\circ}$ hydrol & 70.904 & 2.954 & - & $2,9 \%$ \\
\hline \multirow{2}{*}{ Gas engine } & (A) Mixed sludge & 30.779 & 1.282 & 1.181 & $10,8 \%$ \\
\hline & (B) $1^{\circ}$ non-hydrol $+2^{\circ}$ hydrol & 28.493 & 1.187 & 1.093 & $7 \%$ \\
\hline
\end{tabular}

${ }^{a}$ Energy involved in the production of the steam needed for the process.

${ }^{b}$ Sludge concentration for a self-sufficient process.

Meets US EPA Class A criteria - pathogen free.

\section{ACKNOWLEDGMENTS}

The authors would like to express their gratitude to the Vic municipal wastewater treatment plant staff for technical support.

\section{REFERENCES}

BOUGRIER, C.; CARRÈRE, H.; BATTIMELLI, A. and DELGENÈS J.P. Effects of various pre-treatments on waste activated sludge in order to improve matter solubilization and anaerobic digestion. In: Proceedings of $10^{\text {th }}$ World Congress on Anaerobic Digestion. (29 $9^{\text {th }}$ August $-2^{\text {nd }}$ September, 2004, Montréal, Canada), vol. II, p. 998-1003.

CAMACHO, P.; DÉLÉRIS, S.; GEAUGEY, V.; PAUL, E. and GINESTET, P. A comparative study between mechanical, thermal and oxidative disintegration technique of waste activated sludge. Water Science and Technology, 2002, vol. 46, no. 10, p. 79-87.

CARBALLA, M.; OMIL, F. and LEMA, M. Improvement of anaerobic digestion operation and digested sludge characteristics using a chemical and thermal pre-treatment. In: Proceedings of $10^{\text {th }}$ World Congress on Anaerobic Digestion. (29 $9^{\text {th }}$ August - $2^{\text {nd }}$ September, 2004, Montréal, Canada), vol. II, p. 1004-1009.

CHU, C.P.; FENG, W.H.; CHANG, B.W.; CHOU, C.H. and LEE, D.J. Reduction in microbial density level through freezing and thawing. Water Research, 1999, vol. 33, no. 16, p. 3532-3535.

DÉLÉRIS, S.; GEAUGEY, V.; CAMACHO, P.; DEBELLEFONTAINE, $\mathrm{H}$. and PAUL, E. Minimization of sludge production in biological processes: an alternative solution for the problem of sludge disposal. Water Science and Technology, 2002, vol. 46, no. 10, p. 63-70.

DÉLÉRIS, S.; PAUL, E.; AUDIC, J.M.; ROUSTAN, M. and DEBELLEFONTAINE, H. Effect of ozonation on activated sludge solubilization and mineralization. Ozone Science \& Engineering, 2000, vol. 22, no. 5, p. 473-486.

FERNÁNDEZ-POLANCO, F.; VELÁZQUEZ, R.; PEREZ-ELVIRA, S.I.; CASAS, C.; DEL BARRIO, D.; CANTERO, F.J.; FERNÁNDEZ-POLANCO, M.; RODRIGUEZ, P.; PANIZO, L.; SERRAT, J. and ROUGE, $P$. Continuous thermal hydrolysis and energy integration in sludge anaerobic digestion plants. Water Science and Technology, 2008, vol. 57, no. 8, p. 1221-1226.

FERNÁNDEZ-POLANCO, F.; NIETO, P.; PÉREZ ELVIRA, S.I.; VAN DER ZEE, F.P.; FERNÁNDEZPOLANCO, M. and GARCÍA, P.A. Automated equipment for anaerobic sludge parameters determination. Water Science and Technology, 2005, vol. 52, no. 1-2, p. 479-485.

GOEL, R.; KOMATSU, K.; YASUI, H. and HARADA, H. Process performance and change in sludge characteristics during anaerobic digestion of sewage sludge with ozonation. Water Science and Technology, 2004, vol. 49, no. 10, p. 105-113.

HASEGAWA, S.; SHIOTA, N.; KATSURA, K. and AKASHI, A. Solubilization of organic sludge by thermophilic aerobic bacteria as a pre-treatment for anaerobic digestion. Water Science and Technology, 2000, vol. 41, no. 3, p. 163-169.

KEPP, U.; MACHENBACH, I.; WEISZ, N. and SOLHEIM, O.E. Enhanced stabilisation of sewage sludge through thermal hydrolysis - 3 years of experience with full scale plants. Water Science Technology, 2000, vol. 42, no. 9, p. 89-96. 
KEPP, U. and SOLHEIM, O.E. Meeting increased demands on sludge quality - experience with full scale plant for thermal disintegration. In: Proceedings $9^{\text {th }}$ World Congress, Anaerobic Conversion for Sustainability. $\left(2^{\text {nd }}-6^{\text {th }}\right.$ September, 2001, Antwerpen, Belgium).

LEHNE, G.; MÜLLER, A. and SCHWEDES, J. Mechanical disintegration of sewage sludge. Water Science and Technology, 2000, vol. 43, no. 1, p. 19-26.

LI, Y.Y. and NOIKE, T. Upgrading of anaerobic digestion of waste activated sludge by thermal pre-treatment. Water Science and Technology, 1992, vol. 26, p. 857-866.

MÜLLER, J. Disintegration as a key-step in sewage sludge treatment. Water Science and Technology, 2000a, vol. 41, no. 8, p. 123-130.

MÜLLER, J.A. Pre-treatment processes for the recycling and reuse of sewage sludge. Water Science and Technology, 2000b, vol. 42, no. 9, p. 167-174.

MÜLLER, J.A. Prospects and problems of sludge pretreatment processes. Water Science and Technology, 2001, vol. 44, no. 10, p. 121-128.

MÜLLER, J.A.; WINTER, A. and STRÜNKMANN, G. Investigation and assessment of sludge pre-treatment processes. Water Science and Technology, 2004, vol. 49, no. 10 , p. $97-104$.

NEIS, U.; NICKEL, K. and TIEHM, A. Enhancement of anaerobic digestion by ultrasonic disintegration. Water Science and Technology, 2000, vol. 42, no. 9, p. 73-80.

ODEGAARD, H.; PAULSRUD, B. and KARLSON, I. Wastewater sludge as a resource-sludge disposal strategies and corresponding treatment technologies aimed at sustainable handling of wastewater sludge. Water Science and Technology, 2002, vol. 46, no. 10, p. 295-303.

ODEGAARD, H. Sludge minimization technologies - an overview. Water Science and Technology, 2004, vol. 49, no. 10 , p. 31-40.

PÉREZ-ELVIRA S.I.; FERNÁNDEZ-POLANCO F. and FERNÁNDEZ-POLANCO, $M$. Influence of thermal hydrolysis process on sludge properties - Experimental study for mixed sludge. In: $5^{\text {th }}$ International Symposium on Anaerobic Digestion of Solid Wastes and Energy Crops. $\left(25^{\text {th }}-28^{\text {th }}\right.$ May, 2008, Hammamet, Tunisia).

PÉREZ-ELVIRA, S.I.; NIETO-DIEZ, P. and FERNÁNDEZ-POLANCO, F. Sludge minimization technologies. Reviews in Environmental Science and Biotechnology, November 2006, vol. 5, no. 4, p. 375-398.

TANAKA S.; KOBAYASHI T.; KAMIYAMA, K.I. and BILDAN, L.N.S. Effects of thermochemical pre-treatment on the anaerobic digestion of waste activated sludge. Water Science and Technology, 1997, vol. 35, no. 8, p. 209-215.

TIEHM, A.; NICKEL, K.; ZELLHORN, M. and NEIS, U. Ultrasonic waste activated sludge disintegration for improving anaerobic stabilization. Water Research, 2001, vol. 35, no. 8, p. 2003-2009. 


\section{APPENDIX \\ F IGURES}

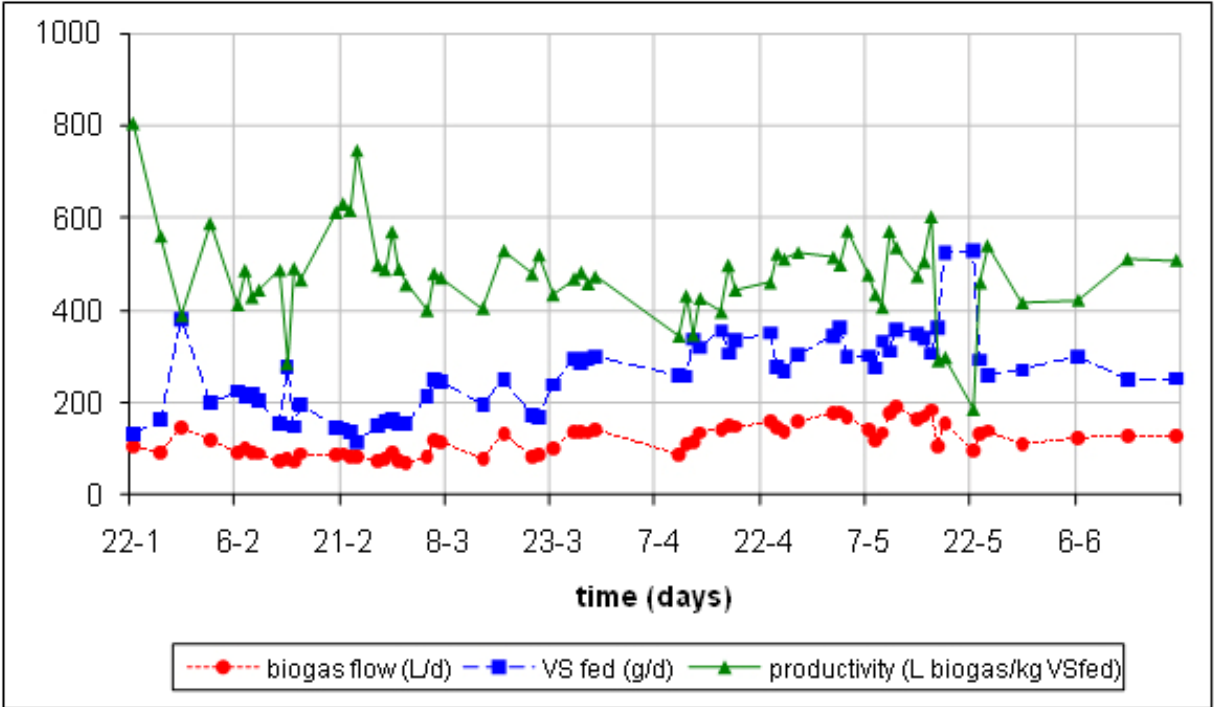

Figure 1. Pilot plant anaerobic digester performance, fed with $3 \%$ TS mixed sludge thermically hydrolyzed.

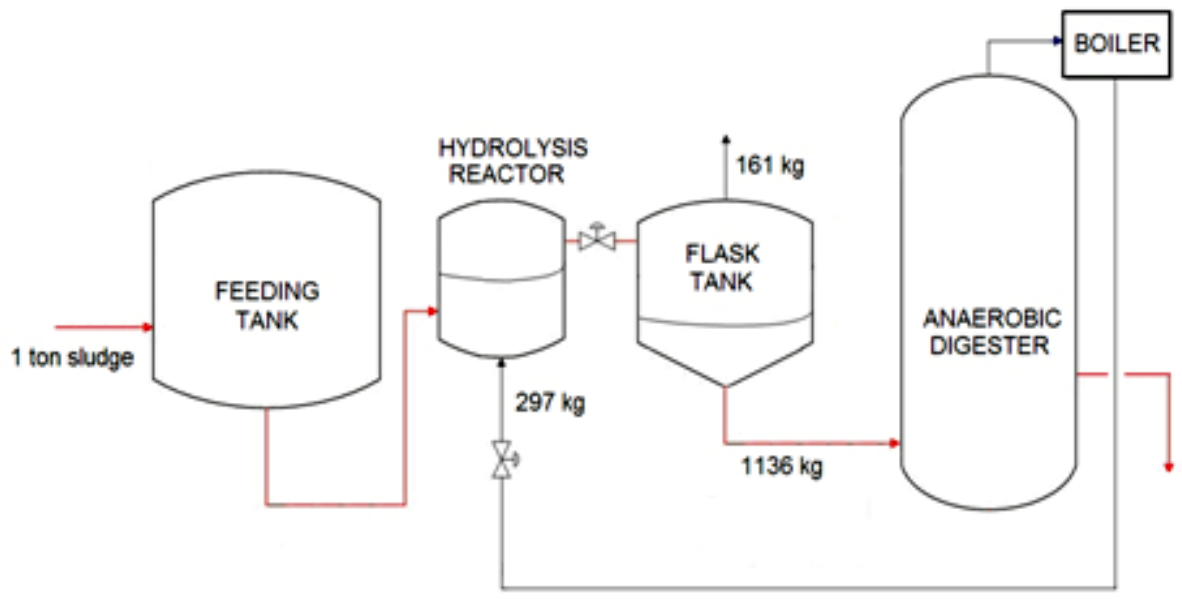

Figure 2. Open scheme of the hydrolysis unit. No energy integration considered.Steam demand for the hydrolysis reactor: $297 \mathrm{~kg}$ steam/ton sludge. 


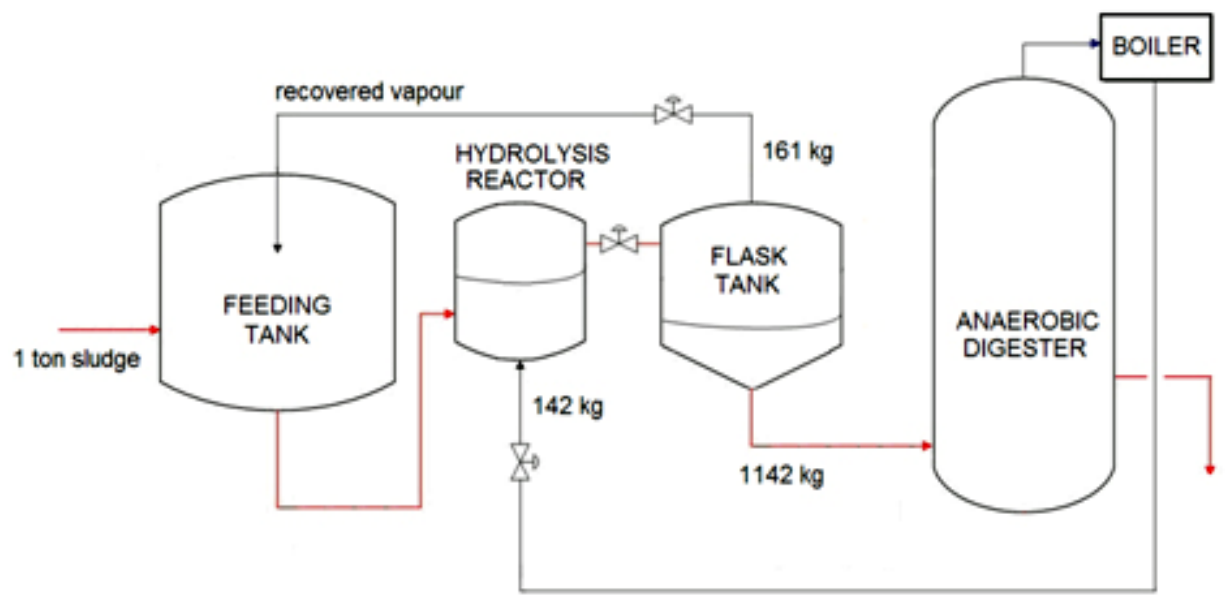

Figure 3. Scheme of the hydrolysis unit with energy recovery of flash vapours to pre-heat the sludge feeding. Steam demand for the hydrolysis reactor: $297 \mathrm{~kg}$ steam/ton sludge.

a

b

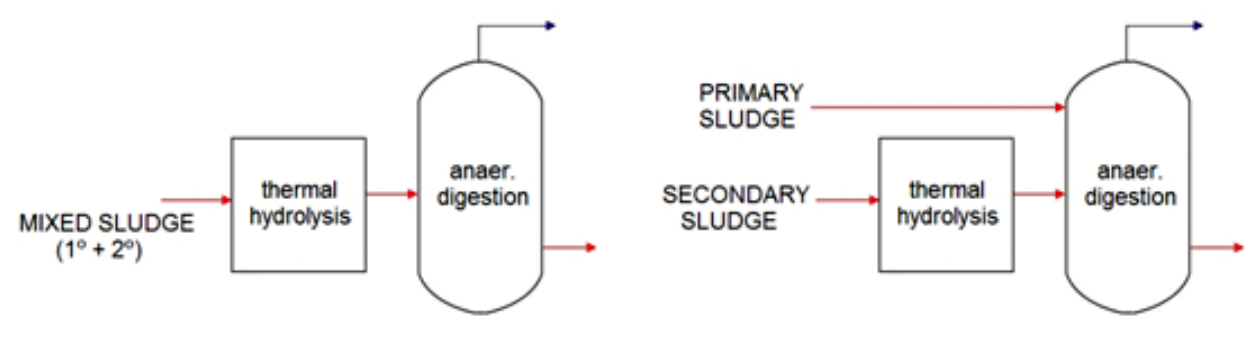

C

d
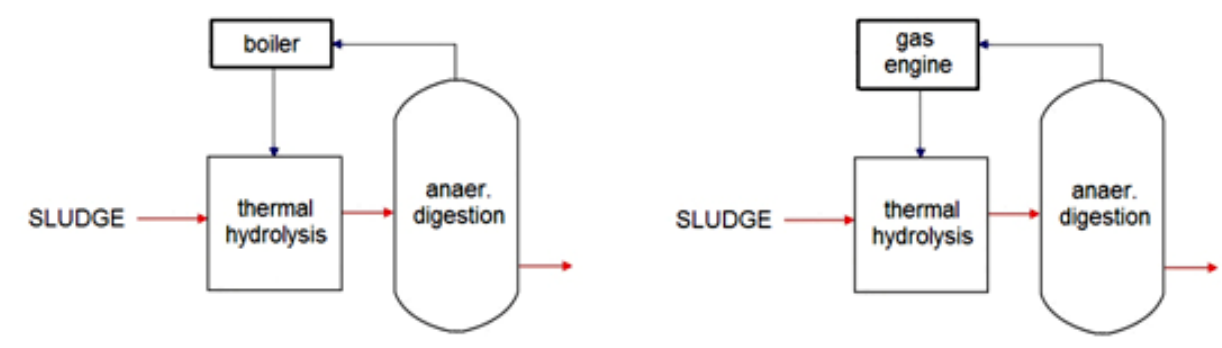

Figure 4. Different configurations for $T H+A D$, regarding feed segregation and steam generation devices.

(a) Scheme A: No feed segregation: mixed sludge to the TH unit.

(b) Scheme B: Feed segregation: only secondary sludge to the TH unit.

(c) Burning the biogas in a boiler to produce power.

(d) Burning the biogas in an engine or turbine to produce power and generate electricity. 
Pérez-Elvira, S.I. et al.

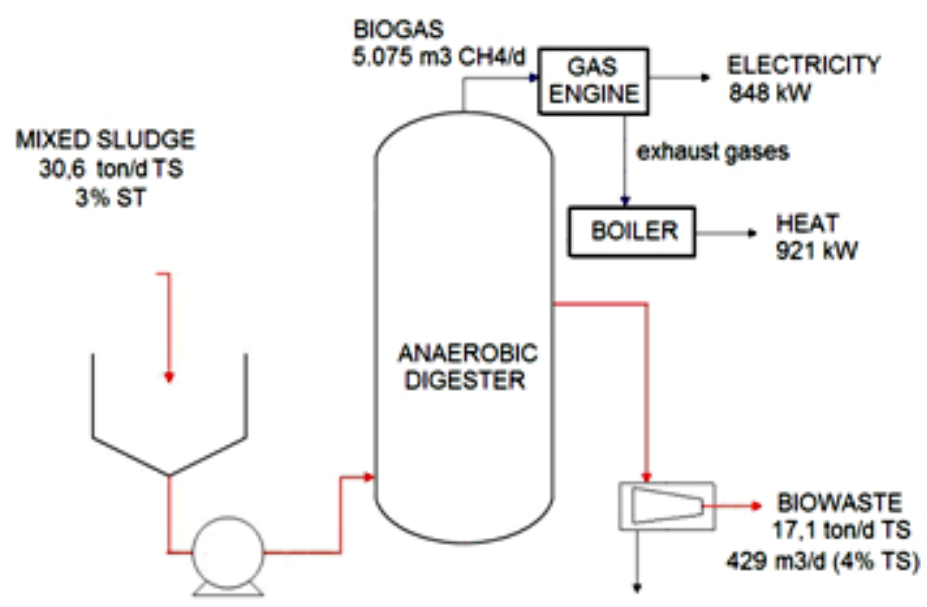

Figure 5. Energy integration flow diagram in the conventional process (AD).

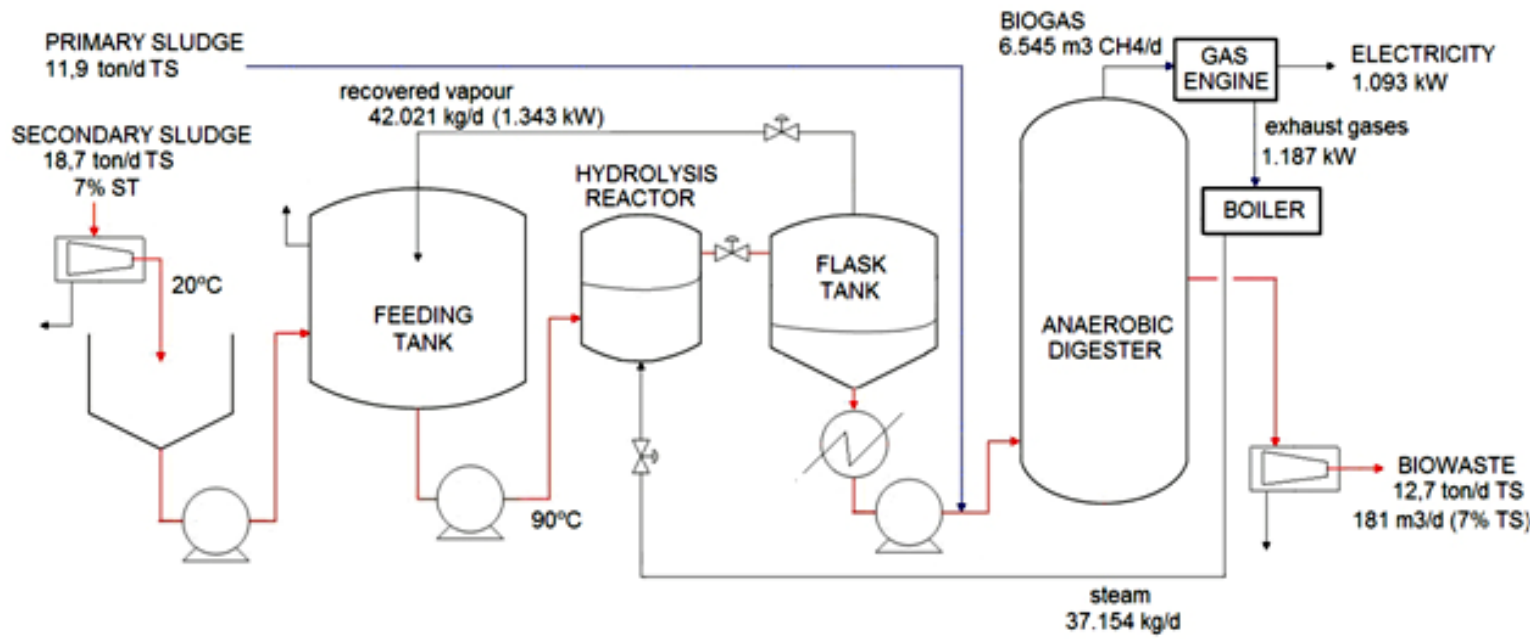

Figure 6. A significant correlation between cellular growth rate of each strain and carotene productivity was found ( $p<0.01)$. 